\title{
Mean- Adjusted Variance Model for Portfolio Optimization
}

\section{Adil Moghar $^{a^{*}}$, Hassan Chikri ${ }^{\text {b }}$, Manar Kassou ${ }^{c}$, Faris Hamza}

a*Economy, Management and Sustainable Development Department, Abdelmalek Essaâdi, Tétouqn, Morocco. E-mail: adilmoghar@gmail.com

${ }^{\mathrm{b} E}$ Economy, Management and Sustainable Development Department, Abdelmalek Essaâdi, Tétouqn, Morocco. E-mail: hassanchikricpt@gmail.com

'ERISI, National School of Applied Sciences, Abdelmalek Essaadi University, Tétouan, Morocco.

E-mail: mkassou14@gmail.com

${ }^{\mathrm{d}}$ Economy, Management and Sustainable Development Department, Professor at University of Abdelmalek

Essaâdi, Tétouan, Morocco. E-mail: fhamza2004@yahoo.fr

Article History: Received: 11 January 2021; Accepted: 27 February 2021; Published online: 5 April 2021

\begin{abstract}
This paper proposes an operational founded model for portfolio optimization. The procedure used is based on the redacting ofthe asymmetry impact of the variance. This is a new approach that givesassets more accurate risk measures. The risk adjustment is based on the measure of volatility skewness andthe goal here is to eliminate noisy risk.Moreover, we give our risk asymmetrical effect,according to the means of each asset.
\end{abstract}

Keywords: Portfolio Optimization, Asymmetry, Return Adjusted, Volatility Skewness.

\section{Introduction}

The stock market collapse in 2008 inadvertently highlighted the importance of market risk in portfolio management. Market risk is defined as the risk related to the fluctuation of the market portfolio. The study of portfolio risk management goes back to the fundamental work of Markowitz in 1952. Markowitz was the first to propose the mean-variance optimization framework.

The portfolio optimization problem consists of choosing a specific number of assets that meet investors' objectives, Mansinia et al. (2014).The most recent research topic involves calculating the proportion of the initial budget that should be allocated in the available securities.

Since Markowitz mean-variance theory, many papers have been published extending or modifying the basic model (e.g.) Alexander \& Baptista (2004); Benati \& Rizzi (2007); Mansini et al. (2007); Ogryczak (2000); Sawik (2013a), (2013b), (2012a), (2012b), (2012c), (2011), (2010a), (2010b), (2009a), (2009b), (2009c), (2008); Speranza (1993); Iancu \& Trichakis (2014); Terradez et al. (2015) Hamza \& Janssen (1998).

The mean-variance model plays an important role in portfolio management. Additionally, the mean-variance analysis is essential to many asset pricing theories. Despite its reputation, dissemination, and adoption in the financial field, the theory of mean-variance optimization has been the subject of strong criticism since its publication. Numerous practitioners have reported some complications in implementing mean-variance analysis.

One of the most common criticisms of the Markowitz theory is its lack of robustness. Among other things,the mean-variance theory is particularly sensitive to the estimation of two parameters (mean and variance-covariance matrix).

Many authors have shown that the parameters generally tend to be unstable when estimated from a sample of historical data. Another criticism of this theory is based on the variance as a risk measure.However, the main drawback of the variance is that it penalizes both upward and downward deviations (i.e. both losses and profits).

Several research fields have developed this theory to try to correct the perceived shortcomings in the assumptions, the empirical results, and extend its application to other areas, Baker \&Filbeck (2013).

The purpose of this study is to find the best possible allocation for any portfolio. Our techniqueattempts to equalize the upwards and downwards risk spread. Nevertheless, incase the downward deviations are lower than the upward ones,this equalization will be done according to the part that represents the real risk for the investor.In this case, the positive deviation does not represent a risk, we also keep the symmetrical shape to give the assets an equal chance for profit and loss. This process will reduce the risk of our portfolio and make it more efficient.

This article is organized as follows. The second section contains the literature review on the different risk optimization theory and its limitations. The third section presents the data, methodology, and technics used. Then the $4^{\text {th }}$ section covers all the results and discussion while the last section concludes our work. 


\section{Literature Review}

In the capital market, selecting security or asset by the investors has never been a simple matter. Markowitz was the first to formalize the tradeoff between risk and return of a portfolio. He proposed the mean-variance optimal portfolio. Thus, this theory suggests that portfolio risk is measured by variance, and the main goal is to minimize it for a certain average return. Markowitz's mean-variance optimization theory was considered the heart of the modern portfolio theory. Better yet, the study of the correlation between the securities led him to develop the portfolio diversification strategy, which is often more expressive under the quote "Never put all your eggs in one basket".

In pioneering work, Markowitz (1952) combined probability theory and optimization theory to model the investment behavior ofeconomic agents. Accordingly, In his analysis, he stated that the investment return should be quantified as the expected value and risk as to the variance.

Furthermore, Markowitz made his models as follows: minimizing variance subject to a lower limit on expected returns or maximizing expected returns subject to a minimal level of variance. The main contribution of this model is relatively general, allowing its use and simplicity, in terms of theoretical analysis, in many practical situations.

To develop this model, Markowitz relies on a very restrictive assumption. He assumed that the returns on financial assets follow a normal distribution. So, Markowitz uses only the first two moments of the distribution: mean and variance in his model.Thereafter, several researchers Grama \&Schyns (2003);Deng, Li, \& Wang (2005) took variance to measure the risk in various situations. Although the variance is a very popular measure of risk in the portfolio selection, it has some limitations, Markowitz (1959).

One of the main limitations is that the variance considers extremely high returns as equal to low returns. When security's returns are asymmetric, the selected portfolio based on variance may have a potential anomaly that sacrifices too much-expected return to eliminate both extremely high and low returns. Also, there is some empirical study showing that many security returns are not distributed symmetrically. Liu, Wang, \& Qiu (2003); Prakash, Chang \& Pactwa (2003); Yan \& Li(2009); Guo, Li, Zou, Guo, \& Yan (2012).

It was argued that the definition of risk as the variance of expected returns is justified only when expected returns are normally distributed and when investors have quadratic utility functions, these two assumptions are not valid in practice,Feldstein (1969). According to the classic portfolio model, the use of the first two moments of distributions leads to a suboptimal allocation of assets Bawa \& Lindenberg (1977); Harlow \& Rao (1989); Harlow (1991).

The variance-covariance measurement of risk is somewhat controversialJeffrey (1984). In this context, the semi-variance was proposed by Markowitz (1959) to replace the variance as a measure of risk in portfolio selection. Markowitz (1959)suggested the use of semi-variance instead of variance in his asset allocation model. In this case, excess returns above the average collapse to zero so that they do not correspond to the variances unnecessarily, resulting in intuitively better asset allocation. Semi-variance proved to be a more accurate measure of risk, not only for asset allocation but also for assessingMao (1970).

Having established that mean-semi-variance is an approximately correct criterion in the sense that it provides a level of utility highly correlated with the expected utility of an investor.Thereby, we will now consider some additional reasons that support the plausibility of the semi-variance as a measure of risk.

Some of these reasons are practical, some others are empirical. From a practical perspective, first of all, investors do not dislike upside volatility; they only dislike downside volatility. Secondly, semi-variance is more useful than the standard deviation when the underlying distribution of returns is asymmetric and just as useful when the underlying distribution is symmetric i.e. the semi-variance is at least useful as a measure of risk as tothe standard deviation. Finally, the semi-variance combines into one measure the information provided by two statistics: variance and skewness. Thus, making it possible to use a one-factor model to estimate the required returns.

From an empirical perspective, semi-variance was reported to explain the cross-section of emerging market returns Estrada (2000); Harvey (2000), the cross-section of industries in emerging markets Estrada (2001), and the cross-section of Internet stocks return Estrada (2004). Additional support for the semi-variance as an appropriate measure of risk is inClash (1999); Hamza \& Janssen (1998); Hamza \& Janssen (2009); Sortino \&van der Meer (1991) and Sortino et al (1999) among others. 
Many studies have noted that the distribution of asset return is rarely normal and that the first two moments are not enough when we consider portfolio risk.Similarly, numerous studies have focused on skewness, kurtosis, and higher moments in portfolio selection Samuelson (1970); Rockinger \&Jondeau (2002).

Tobin (1958) and Rubinstein (1973) showed that higher moments must be taken into account in portfolio selection and that the utility function is not quadratic,along withSamuelson (1970), Rubinstein (1973); Scott \& Horvath (1980); Lai (1991); Konno \& Suzuki (1995); Chunhachinda et al (1997); Fang \& Lai (1997); Prakash et al (2003); Lai et al. (2006).

Empirical evidence given by Arditti (1971)showed that stock return distributions are often positively skewed, and the investor's preference for more skewed distribution rather than less is consistent with the notion of decreasing absolute risk aversion, a positively skewed asset return indicates an elongated right tail in the density function of the asset return Arditti (1967).

Konno et al. (1993) andKonno \& Suzuki (1995) argued that the skewness of the returns and the third-order derivative of a utility function play significant roles in choosing an optimal portfolio. Investors would prefer a portfolio with a larger third moment if the mean and variance are the same. They suggested a mean-varianceskewness (MVS) portfolio optimization approach.This could have been able to make it possible to calculate an approximated efficient frontier of mean-variance-skewness and to calculate a portfolio with the maximal expected utility for any decreasingly risk aversion utility function using this model. However, they failed to solve the meanvariance-skewness model but instead reported preliminary computational results.

A non-parametric approach for measuring efficiency in the case of the static portfolio selection problem based on the mean-variance-skewness space was proposed by Briec et al. (2007). They defined a shortage function that looks for increases in return and skewness and decreases in variance. Overall, optimality is guaranteed for the resulting optimal portfolio.

\section{Data and Methodology}

This section provides an overview of the data used in this study,as well as the model usedto equalize the two semi-variances. This equalization eliminates some unnecessary and detrimental risks from the portfolio.

\subsection{The Adjusted Return Risk Portfolio Selection Model}

The proposed model in this paper aims to make the risk symmetric concerning the means. Here, we target a baying strategy (no short selling allowed) if the upside risk is greater than the downside risk (upsemi-variance greater than the downsemi-variance). We will, therefore, proceed to the reduction of the positive risk to equalize the up and downsemi-variance given by the assets. To implement this model, the change will be applied to returns, the new adjusted returns (output of our model) will only be used to calculate the variance-covariance matrix, while the portfolio's return will not be changed (using the original returns). The goal behind this change is to remove noisy unwanted shock that can affect the risk in case of abuying strategy.

The purpose of this change is to eliminate the detrimental risk caused by shocks for ourportfolio. In the case of a buying strategy, investors consider only the risk of loss, while the risk associated with the asset sometimes obscures its real image.For instance, in Table-1, 'CELG'assets have a positive return, but the down semi-variance is less than the up one. In this case,investors choosing this asset, don't know that their chance of obtaining a positive shock is greater than that of a negative one.

So, the risk of losing is not only related to the downside risk, but there is also the fact of what we can gain from this asset and the chances of having positive shocks. So, we conclude that this asset (CELG) responds more to positive shocks than to negative ones; the upside risk is also important in portfolio assets selection.

The return is calculated according to the following formula:

$$
r_{i}=\log \frac{p_{t}}{p_{t-1}}
$$

Where $p_{t}$ is the asset's price

Given any combination of our risky assets and a set of weights describing the distribution of our portfolio, the overall expected portfolio return formula is:

$$
E\left(r_{p}\right)=\sum_{i=1}^{n} x_{i} E\left(r_{i}\right)
$$


Where $\sum_{i=1}^{n} x_{i}=1$

$n \quad$ Is the number of securities;

$x_{i} \quad$ Is the proportion of the funds invested in security $i$;

$r_{i} \quad$ Is the return of security $i$

$r_{P}$ Is the portfolio return;

The return computation is nothing more than finding the weighted average return of the securities included in the portfolio.

The variance is the expectation of the squared deviation of a random variable from its mean. Informally, it measures how far a set of (random) numbers is spread out from their average value. The variance is the square of the standard deviation.

The portfolio variance is a measurement of how the combined returns of a set of securities make up a portfolio fluctuate over time. This portfolio variance statistic is calculated using the variance of each security in the portfolio as well as the covariance of each security pair in the portfolio:

$$
\operatorname{Var}\left(r_{p}\right)=\sum_{i=1}^{N} \sum_{j=1}^{N} x_{i} x_{j} \sigma_{i j} \operatorname{Cov}\left(r_{i} r_{j}\right)
$$

Covariance can also be expressed in terms of the correlation coefficient:

$$
\operatorname{Cov}\left(r_{i}, r_{j}\right)=\rho_{i j} \sigma_{i} \sigma_{j}=\sigma_{i j}
$$

Whereby $\rho_{i j}$ is the correlation coefficient between returns.

We can measure the degree of returns asymmetry using the Skewness coefficient. Considering that a simple test of the symmetry hypothesis consists in testing the nullity of the central third order moment of the distribution, the Skewness coefficient defined as:

$$
\operatorname{skew}(X)=\frac{E[X-E(X)]^{3}}{[\operatorname{var} X]^{3 / 2}}
$$

For a significant negative Skewness coefficient, the distribution is asymmetric. This means that the probability of getting below-average values is higher than that of getting higher than average values and vice versa for positive skewness.

The flattening coefficient or Kurtosis of a random variable corresponds to its fourth-order centered moment. Kurtosis is a measure of the thickness of the tails of distributions. This measure is based on the normal distribution, which is considered a flat-tailed distribution and has a flattening coefficient of 3 . If the Kurtosis exceeds 3 , then the distribution tails are thick and the distribution is called leptokurtic. If the Kurtosis is less than 3, the distribution is called Platykurtic. Kurtosis's formula exclaims as follows:

$$
\operatorname{kurt}(X)=\frac{E[X-E(X)]^{4}}{[\operatorname{var} X]^{2}}
$$

\subsubsection{Semi-variance}

The semi-variance of asset returns is a better risk measurement way for several reasons. First of all, investors 'like' more positive volatility than the negative ones. Second, semi-variance is more useful than the variance when the distribution is asymmetric, and it is also beneficial when the distribution is symmetrical. Third, semi-variance providesinformation about two dimensions: variance and skewness, Estrada (2007). Consequently, investors require higher returns from the shares, which have high downside risk deviations. They do not buy shares, as long as they become cheaper to an appropriate level. In the meantime, the shares with high positive deviation risk are overestimated and acquired for high prices, Ishiba et al. (2012).

The semi-variance can be estimated (using historical data)asfollow: 


$$
\left\{\begin{array}{l}
S V^{+}{ }_{j}=\frac{1}{T} \sum_{t=1}^{T} \sum_{j=1}^{n} \max \left(0, r_{j, t}-E\left(r_{j}\right)\right)^{2} \\
S V^{-}{ }_{j}=\frac{1}{T} \sum_{t=1}^{T} \sum_{j=1}^{n} \min \left(0, r_{j, t}-E\left(r_{j}\right)\right)^{2}
\end{array}\right.
$$

\subsubsection{Volatility Skewness}

Volatility Skewness is the ratio of a distribution's upside variance to its downside variance, where the variances are measured relative to the mean. If the distribution is symmetrical, it has a skewness of 1.00. The values greater than 1.00 indicate positive skewness and values less than 1.00 indicate negative skewness, Sortino (2009).

Some critics of downside risk claim that eliminating the upside returns, from the risk calculation, is incorrect since strong positive returns somehow imply the inevitability of correspondingly strong negative returns. This criticism is anecdotal and is unsupported by any published research Sortino (2009).

As previously stated, it is necessary to fit some distribution to the observed return-data points into accurately calculated downside risk and related statistics. However, this is no different from the traditional method used in the MPT analysis in which the normal distribution is assumed to infer probabilities of loss from the observed data points.

The Volatility of Skewness can be estimated (using historical data) as follows:

$$
\begin{aligned}
& V_{-} \operatorname{Skew}_{j}=\frac{\frac{1}{T} \sum_{t=1}^{T} \sum_{j=1}^{n} \max \left(0, r_{j, t}-E\left(r_{j}\right)\right)^{2}}{\frac{1}{T} \sum_{t=1}^{T} \sum_{j=1}^{n} \min \left(0, r_{j, t}-E\left(r_{j}\right)\right)^{2}} \\
& j=1,2, \ldots, n
\end{aligned}
$$

The method proposed in this paper, as we have mentioned, uses the volatility skewness as a corrective term to adjust the upside risk. Our strategies aim to equalize the down and upside risks.Making the risk of our assets symmetrical will help to reduce and eliminate anyunnecessary risk that was involved implicitly in our portfolio.

The method consisted of dividing the upside deviation according to the means of all the returns by the square root of the volatility skewness coefficient of each asset.

$$
A^{+}=\frac{\max \left(0, r_{j, t}-E\left(r_{j}\right)\right)}{\sqrt{V_{-} \text {Skew }_{j}}}
$$

To recompose the adjusted returns, we recomposed all the elements to obtain a new return for each asset.The new return will be similar to the original ones but with a very small difference that can be noticed in figure 1 .

The new returns obtained are given by the formula:

$$
\begin{aligned}
& r>0 \text { and } S V^{+}{ }_{j}>S V^{-}{ }_{j} \\
& r^{*}=\frac{\max \left(0, r_{j, t}-E\left(r_{j}\right)\right)}{\sqrt{V_{-} \text {Skew }}}+\min \left(0, r_{j, t}\right)+E\left(r_{j, t}\right)
\end{aligned}
$$

This new return (adjusted return) will be used only to calculate the variance-covariance matrix. The variance calculation based on the new returns has equal semi-variances. To implement the change in the mean-variance model, we need to substitute the old variance-covariance matrix with the new matrix calculatedby using the adjusted returns.

Then, the optimization program will be written as follow.

$$
\text { Minimize } \quad \sum_{i=1}^{n} \sum_{J=1}^{n} x_{i} x_{j} \sigma_{i j}{ }^{*}
$$

Subject to 


$$
\begin{gathered}
\sum_{j=1}^{n} x_{j} E\left[r_{j}\right]>\rho \\
\sum_{j} \geq 0 \quad x_{j=1}^{n}=1 \\
j=1, \ldots, n
\end{gathered}
$$

This is a quadratic programming problem, having $\mathrm{n}$ variables and two linear constraints. The term $\sigma_{i j}{ }^{*}$ is calculated using the adjusted returns resulted from our method. These constraints can significantly change the efficient frontier. As a result, $\mathrm{x}_{\mathrm{j}}$ can be negative if the assetis issued by the investor, or in case of short selling.

This system can be written as the following matrix form:

Minimize

$$
X^{T} \sum X
$$

$$
\left[\begin{array}{c}
x_{1} \\
x_{2} \\
\cdot \\
\cdot \\
\cdot \\
x_{j}
\end{array}\right] \times\left[\begin{array}{rrrr}
\sigma_{11}{ }^{*} & \sigma_{12}{ }^{*} & \ldots & \sigma_{1 j}{ }^{*} \\
\sigma_{11}{ }^{*} & \sigma_{12}{ }^{*} & \ldots & \sigma_{1 j}{ }^{*} \\
& \cdot & & \\
& \cdot & & \\
& \cdot & \\
\sigma_{11}{ }^{*} & \sigma_{12}{ }^{*} & \ldots & \sigma_{1 j}{ }^{*}
\end{array}\right]\left[\begin{array}{llll}
x_{1} x_{2} & \ldots & x_{j}
\end{array}\right]
$$

Subject to

$$
\begin{gathered}
{\left[\begin{array}{ll}
x_{1} x_{2} \ldots & x_{j}
\end{array}\right] \times\left[\begin{array}{c} 
\\
R_{1} \\
R_{2} \\
\vdots \\
R_{J}
\end{array}\right] \geq \rho} \\
x_{1}+x_{2}+\cdots x_{j}=1 \\
R_{j}=E\left[r_{j}\right] \quad j=1, \ldots, n
\end{gathered}
$$

\subsection{Presentation and Description of Data}

Our study sample includes data corresponding to the historical returns of 24 financial assets from the NYSE market. The data covers the period from $1 / 5 / 2017$ to $12 / 28 / 2017$. The returns are based on the price of securities from different activity areas, such as the Industrial sector, Finance, Transport, Services, etc. For our simulation, we used an expected return rate of $0.05 \%$ per unit of time (one week). Our work is mostly achieved by using MATLAB financial toolbox.

To describe the statistical of our data, table 1 shows the average return, variance, skewness, kurtosis, the skewness as well as kurtosis after adjustment, the negative and positive semi-variance, and finally the volatility skewness for all 24 assets.

According totable 1, we can conclude that the weekly returns distribution of all assets is different from the normal distribution. Additionally, the adjusted volatility has less value than the original one.Accordingly, this confirms that our model has shrunken some of the risks of our assets, whichis noticeable in the result of our portfolio optimization. In terms of skewness, almost all the securities (i.e. 24 securities) are asymmetric (Skewness $\neq 0$ ). For the kurtosis coefficient, we observe that all of the assets have a coefficient above or below three (Kurtosis $\neq 3$ ). The returns with a high kurtosis coefficient imply that the investor will experience occasional extreme returns (either positive or negative). After applying our model, the kurtosis shows less value than the original one. This will reduce some of the occasional extreme returns. However, in this case, we have reduced the extremely positive return because the Kurtosis coefficient does not differ from the positive to the negative ones. The adjustment of our portfolio returns is done using the volatility skewness coefficient. This adjustment is applied to assets characterized by having a positive semi-variance greater than the negative one. 
Table 1. Descriptive Statistics of the data

\begin{tabular}{|c|c|c|c|c|c|c|c|c|c|c|}
\hline $\begin{array}{l}\text { Ass } \\
\text { ets }\end{array}$ & $\begin{array}{l}\text { average } \\
\text { return }\end{array}$ & $\begin{array}{l}\text { vari } \\
\text { ance }\end{array}$ & $\begin{array}{l}\text { variance after } \\
\text { adjustment }\end{array}$ & $\begin{array}{l}\text { (-) Semi- } \\
\text { variance }\end{array}$ & $\begin{array}{l}\text { (+) Semi- } \\
\text { variance }\end{array}$ & $\begin{array}{l}\text { volatility } \\
\text { skewness }\end{array}$ & $\begin{array}{l}\text { skew } \\
\text { ness }\end{array}$ & $\begin{array}{l}\text { Kurt } \\
\text { osis }\end{array}$ & $\begin{array}{l}\text { skewness after } \\
\text { adjustment }\end{array}$ & $\begin{array}{l}\text { kurtosis after } \\
\text { adjustment }\end{array}$ \\
\hline $\begin{array}{l}\text { BI } \\
\text { DU }\end{array}$ & 0.0062 & $\begin{array}{l}0.00 \\
11\end{array}$ & 0.0011 & 0.0005479 & 0.0005316 & 0.9850 & $\begin{array}{l}0.020 \\
1\end{array}$ & $\begin{array}{l}3.43 \\
08\end{array}$ & 0.0201 & 3.4308 \\
\hline $\begin{array}{l}\text { MD } \\
\mathbf{L Z}\end{array}$ & -0.0008 & $\begin{array}{l}0.00 \\
02\end{array}$ & 0.0002 & 0.0001332 & 0.0001111 & 0.9133 & $\begin{array}{l}- \\
0.167 \\
3\end{array}$ & $\begin{array}{l}2.15 \\
39\end{array}$ & -0.1673 & 2.1539 \\
\hline $\begin{array}{l}\mathbf{M} \\
\mathbf{M} \\
\mathbf{M}\end{array}$ & 0.0060 & $\begin{array}{l}0.00 \\
05\end{array}$ & 0.0004 & 0.0001966 & 0.0002462 & 1.1191 & $\begin{array}{l}0.398 \\
6\end{array}$ & $\begin{array}{l}7.02 \\
81\end{array}$ & 0.1265 & 6.9571 \\
\hline $\begin{array}{l}\text { AA } \\
\text { PL }\end{array}$ & 0.0074 & $\begin{array}{l}0.00 \\
06\end{array}$ & 0.0006 & 0.0003149 & 0.0002711 & 0.9279 & $\begin{array}{l}- \\
0.304 \\
2\end{array}$ & $\begin{array}{l}3.91 \\
42\end{array}$ & -0.3042 & 3.9142 \\
\hline $\begin{array}{l}\mathbf{A B} \\
\mathbf{T}\end{array}$ & 0.0075 & $\begin{array}{l}0.00 \\
03\end{array}$ & 0.0003 & 0.0001564 & 0.0001732 & 1.0521 & $\begin{array}{l}0.157 \\
2\end{array}$ & $\begin{array}{l}2.75 \\
45\end{array}$ & 0.1017 & 2.7423 \\
\hline $\begin{array}{l}\text { AB } \\
\text { BV }\end{array}$ & 0.0103 & $\begin{array}{l}0.00 \\
08\end{array}$ & 0.0005 & 0.0002615 & 0.0004990 & 1.3815 & $\begin{array}{l}1.819 \\
1\end{array}$ & $\begin{array}{l}9.89 \\
71\end{array}$ & 1.1697 & 7.1997 \\
\hline $\begin{array}{l}\text { EB } \\
\text { AY }\end{array}$ & 0.0050 & $\begin{array}{l}0.00 \\
07\end{array}$ & 0.0006 & 0.0003129 & 0.0003404 & 1.0431 & $\begin{array}{l}0.181 \\
3\end{array}$ & $\begin{array}{l}2.78 \\
27\end{array}$ & 0.1350 & 2.7577 \\
\hline $\begin{array}{l}\text { BA } \\
\text { BA }\end{array}$ & 0.0126 & $\begin{array}{l}0.00 \\
13\end{array}$ & 0.0011 & 0.0005532 & 0.0006774 & 1.1066 & $\begin{array}{l}0.372 \\
9\end{array}$ & $\begin{array}{l}2.85 \\
92\end{array}$ & 0.2584 & 2.7753 \\
\hline $\begin{array}{l}\text { BM } \\
\mathbf{Y}\end{array}$ & 0.0019 & $\begin{array}{l}0.00 \\
08\end{array}$ & 0.0008 & 0.0005134 & 0.0003161 & 0.7847 & $\begin{array}{l}- \\
1.407 \\
3\end{array}$ & $\begin{array}{l}8.27 \\
76\end{array}$ & -1.4073 & 8.2776 \\
\hline KO & 0.0026 & $\begin{array}{l}0.00 \\
02\end{array}$ & 0.0002 & 0.0001008 & 0.0000749 & 0.8617 & $\begin{array}{l}- \\
0.583 \\
5\end{array}$ & $\begin{array}{l}3.49 \\
84\end{array}$ & -0.5835 & 3.4984 \\
\hline $\begin{array}{l}\text { CO } \\
\mathbf{P}\end{array}$ & 0.0023 & $\begin{array}{l}0.00 \\
09\end{array}$ & 0.0009 & 0.0004577 & 0.0004339 & 0.9736 & $\begin{array}{l}- \\
0.079 \\
6\end{array}$ & $\begin{array}{l}2.60 \\
98\end{array}$ & -0.0796 & 2.6098 \\
\hline $\begin{array}{l}\mathbf{L} \mathbf{L} \\
\mathbf{Y}\end{array}$ & 0.0029 & $\begin{array}{l}0.00 \\
05\end{array}$ & 0.0005 & 0.0002606 & 0.0001858 & 0.8444 & $\begin{array}{l}- \\
0.672 \\
1\end{array}$ & $\begin{array}{l}3.44 \\
83\end{array}$ & -0.6721 & 3.4483 \\
\hline $\begin{array}{l}\text { XO } \\
\text { M }\end{array}$ & 0.0007 & $\begin{array}{l}0.00 \\
02\end{array}$ & 0.0002 & 0.0001327 & 0.0001062 & 0.8949 & $\begin{array}{l}- \\
0.273 \\
4\end{array}$ & $\begin{array}{l}3.08 \\
66\end{array}$ & -0.2734 & 3.0866 \\
\hline $\begin{array}{l}\text { GI } \\
\text { LD }\end{array}$ & 0.0008 & $\begin{array}{l}0.00 \\
09\end{array}$ & 0.0008 & 0.0003964 & 0.0004780 & 1.0982 & $\begin{array}{l}0.276 \\
9\end{array}$ & $\begin{array}{l}5.05 \\
98\end{array}$ & 0.0953 & 5.0489 \\
\hline HD & 0.0069 & $\begin{array}{l}0.00 \\
03\end{array}$ & 0.0003 & 0.0001492 & 0.0001629 & 1.0448 & $\begin{array}{l}0.028 \\
5\end{array}$ & $\begin{array}{l}3.46 \\
29\end{array}$ & -0.0315 & 3.4999 \\
\hline $\begin{array}{l}\text { IN } \\
\text { TC }\end{array}$ & 0.0045 & $\begin{array}{l}0.00 \\
09\end{array}$ & 0.0005 & 0.0002314 & 0.0006365 & 1.6586 & $\begin{array}{l}2.204 \\
8\end{array}$ & $\begin{array}{l}9.84 \\
62\end{array}$ & 1.3172 & 6.5171 \\
\hline $\begin{array}{l}\text { MC } \\
\text { D }\end{array}$ & 0.0075 & $\begin{array}{l}0.00 \\
02\end{array}$ & 0.0002 & 0.0001085 & 0.0001127 & 1.0192 & $\begin{array}{l}0.265 \\
1\end{array}$ & $\begin{array}{l}5.59 \\
98\end{array}$ & 0.2268 & 5.5591 \\
\hline $\begin{array}{l}\text { NK } \\
\text { E }\end{array}$ & 0.0039 & $\begin{array}{l}0.00 \\
09\end{array}$ & 0.0009 & 0.0004850 & 0.0004354 & 0.9475 & $\begin{array}{l}- \\
0.247 \\
9\end{array}$ & $\begin{array}{l}4.30 \\
49\end{array}$ & -0.2479 & 4.3049 \\
\hline $\begin{array}{l}\mathbf{P E} \\
\mathbf{P}\end{array}$ & 0.0034 & $\begin{array}{l}0.00 \\
02\end{array}$ & 0.0002 & 0.0000888 & 0.0000791 & 0.9438 & $\begin{array}{l}- \\
0.142 \\
0\end{array}$ & $\begin{array}{l}2.05 \\
72\end{array}$ & -0.1420 & 2.0572 \\
\hline $\begin{array}{l}\mathbf{T X} \\
\mathbf{N}\end{array}$ & 0.0077 & $\begin{array}{l}0.00 \\
05\end{array}$ & 0.0004 & 0.0002092 & 0.0002350 & 1.0598 & $\begin{array}{l}0.243 \\
0\end{array}$ & $\begin{array}{l}2.58 \\
68\end{array}$ & 0.1850 & 2.5440 \\
\hline $\begin{array}{l}\mathrm{UN} \\
\mathbf{P}\end{array}$ & 0.0057 & $\begin{array}{l}0.00 \\
05\end{array}$ & 0.0004 & 0.0002122 & 0.0002986 & 1.1864 & $\begin{array}{l}0.616 \\
4\end{array}$ & $\begin{array}{l}2.98 \\
43\end{array}$ & 0.4325 & 2.7561 \\
\hline $\mathbf{V}$ & 0.0069 & $\begin{array}{l}0.00 \\
02\end{array}$ & 0.0002 & 0.0001047 & 0.0001105 & 1.0273 & $\begin{array}{l}0.042 \\
2\end{array}$ & $\begin{array}{l}2.12 \\
07\end{array}$ & 0.0202 & 2.1249 \\
\hline $\begin{array}{l}\text { WB } \\
\text { A }\end{array}$ & -0.0018 & $\begin{array}{l}0.00 \\
07\end{array}$ & 0.0007 & 0.0004258 & 0.0002212 & 0.7207 & $\begin{array}{l}1.237 \\
2\end{array}$ & $\begin{array}{l}5.13 \\
66\end{array}$ & -1.2372 & 5.1366 \\
\hline $\begin{array}{l}\text { W } \\
\text { MT }\end{array}$ & 0.0078 & $\begin{array}{l}0.00 \\
05\end{array}$ & 0.0004 & 0.0001855 & 0.0002882 & 1.2464 & $\begin{array}{l}0.900 \\
0\end{array}$ & $\begin{array}{l}5.23 \\
35\end{array}$ & 0.5162 & 4.7299 \\
\hline
\end{tabular}

In our case, all the assets with a volatility skewness greater than 1 have been changed. After recomposing returns using the formula 10 , the return of our assets is given by the following figure 1 . 

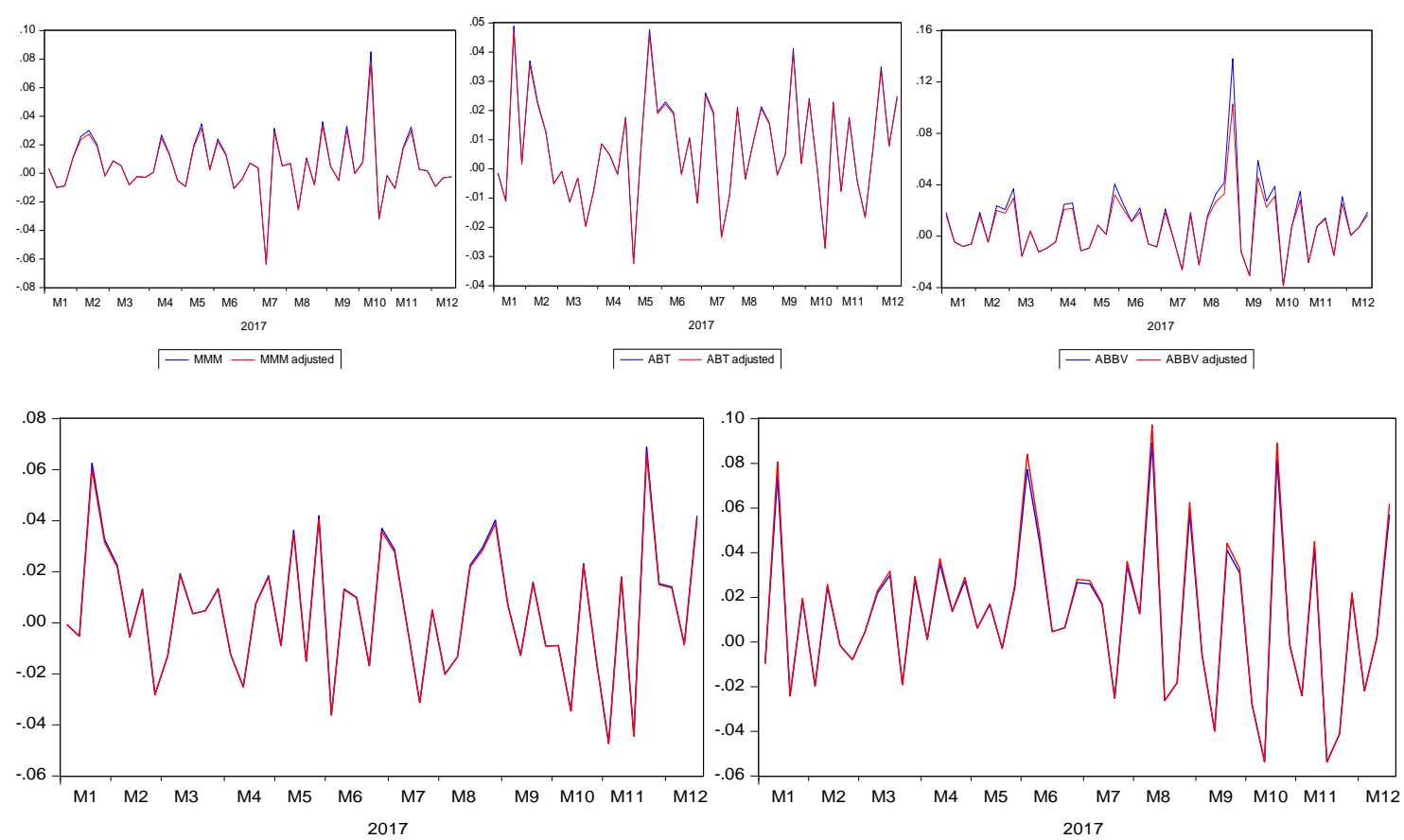

— EBAY — EBAY adjusted

- BABA adjusted — BABA
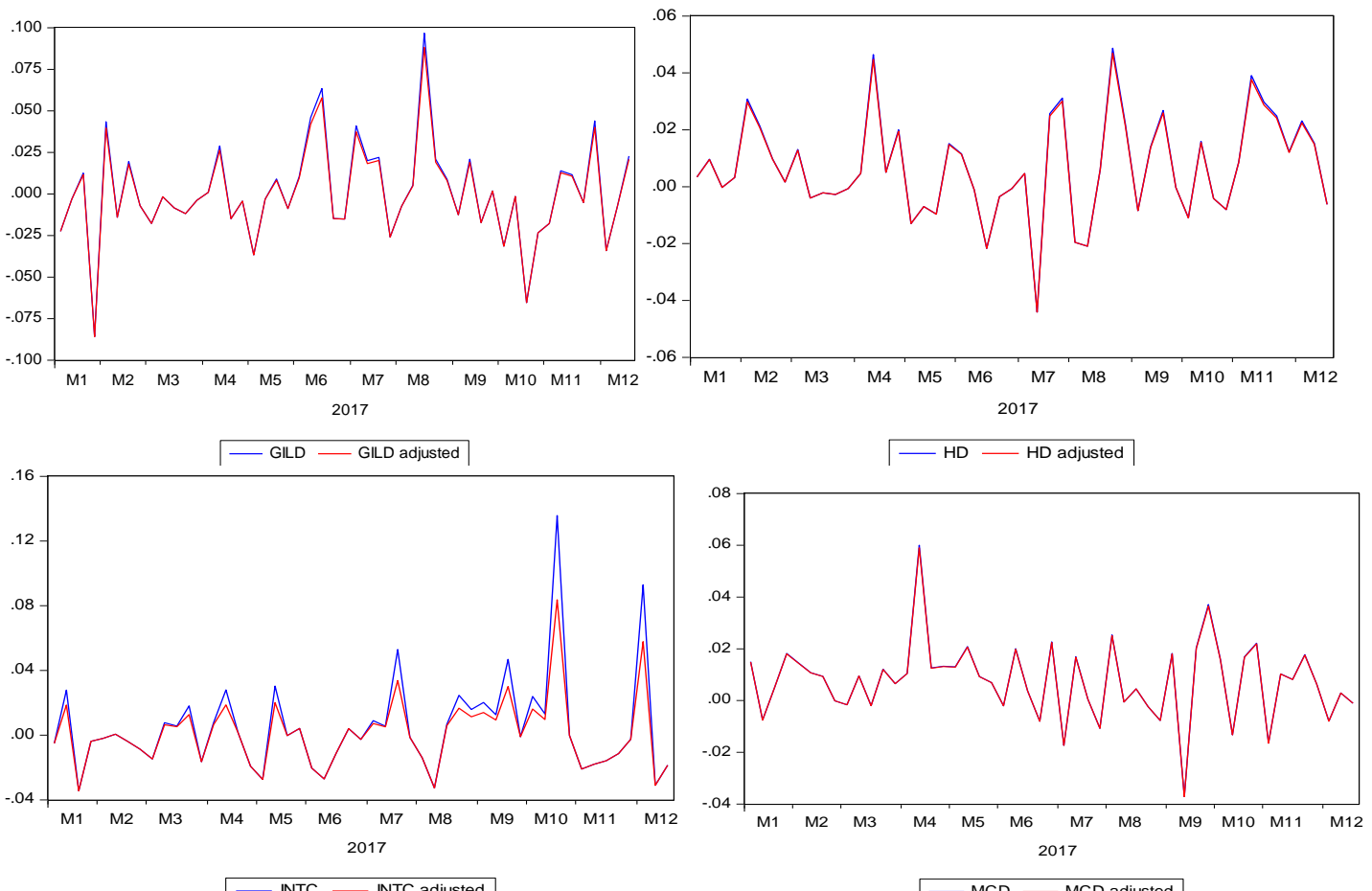

— INTC — $\mathbb{N}$ NTC adjusted

- MCD — MCD adjusted 

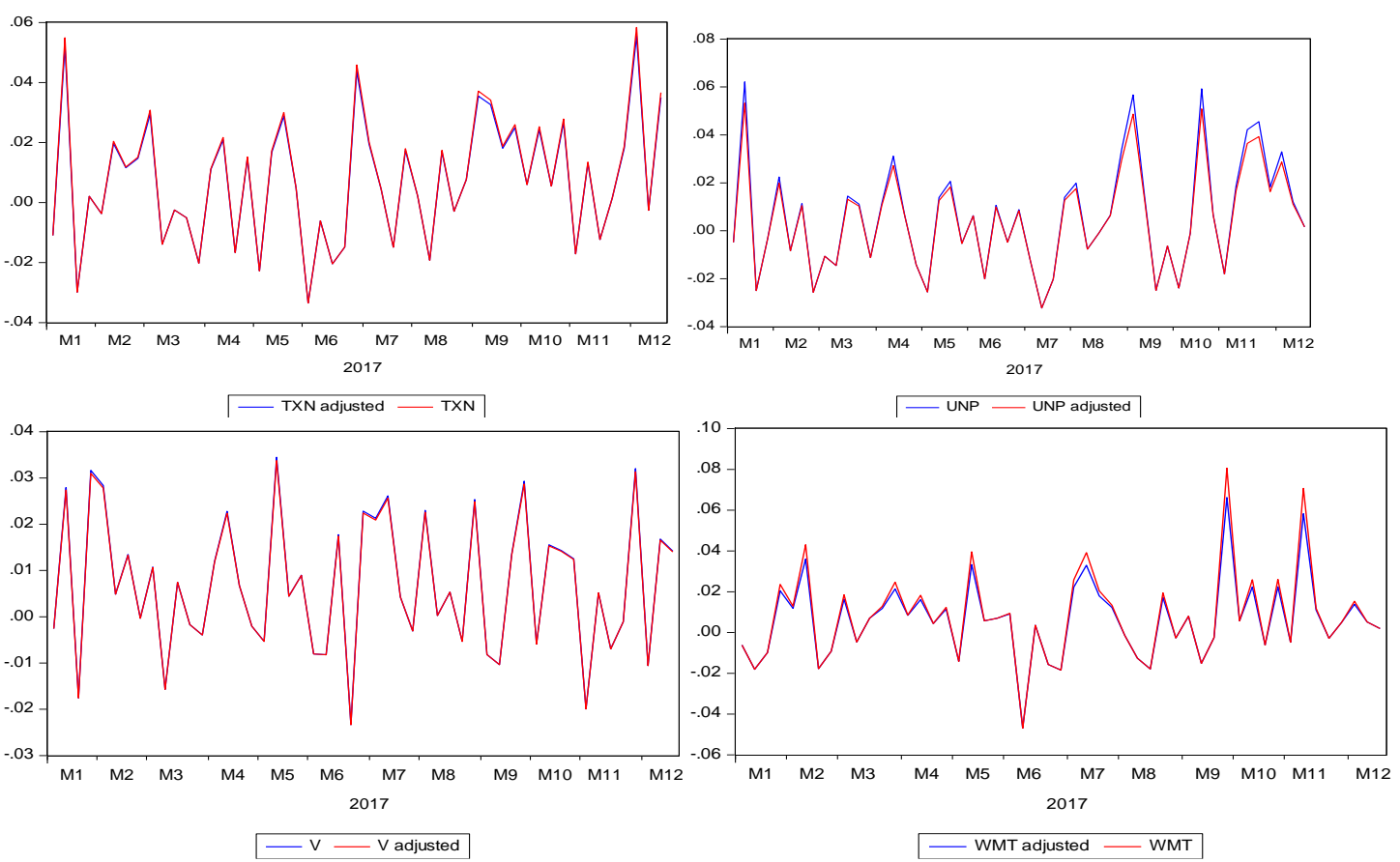

Figure 1. Evolution of portfolio assets' return and their adjustment.

These returns will be used only to calculate the variance-covariance matrix, while the original returns value will be used to calculate the expected return of our portfolio, hence, only the risk of our portfolio will change.

\section{Results and Discussion}

In this section, we preside to applying the original mean-variance model introduced by Markowitz,by using an adjusted variance-covariance matrix. Therefore, through observing the variance- covariance matrix of original and adjusted returns, we can conclude that the adjusted variance-covariance matrix has fewer risk Tables (2) and (3).

Table 2. Variance - Covariance matrix

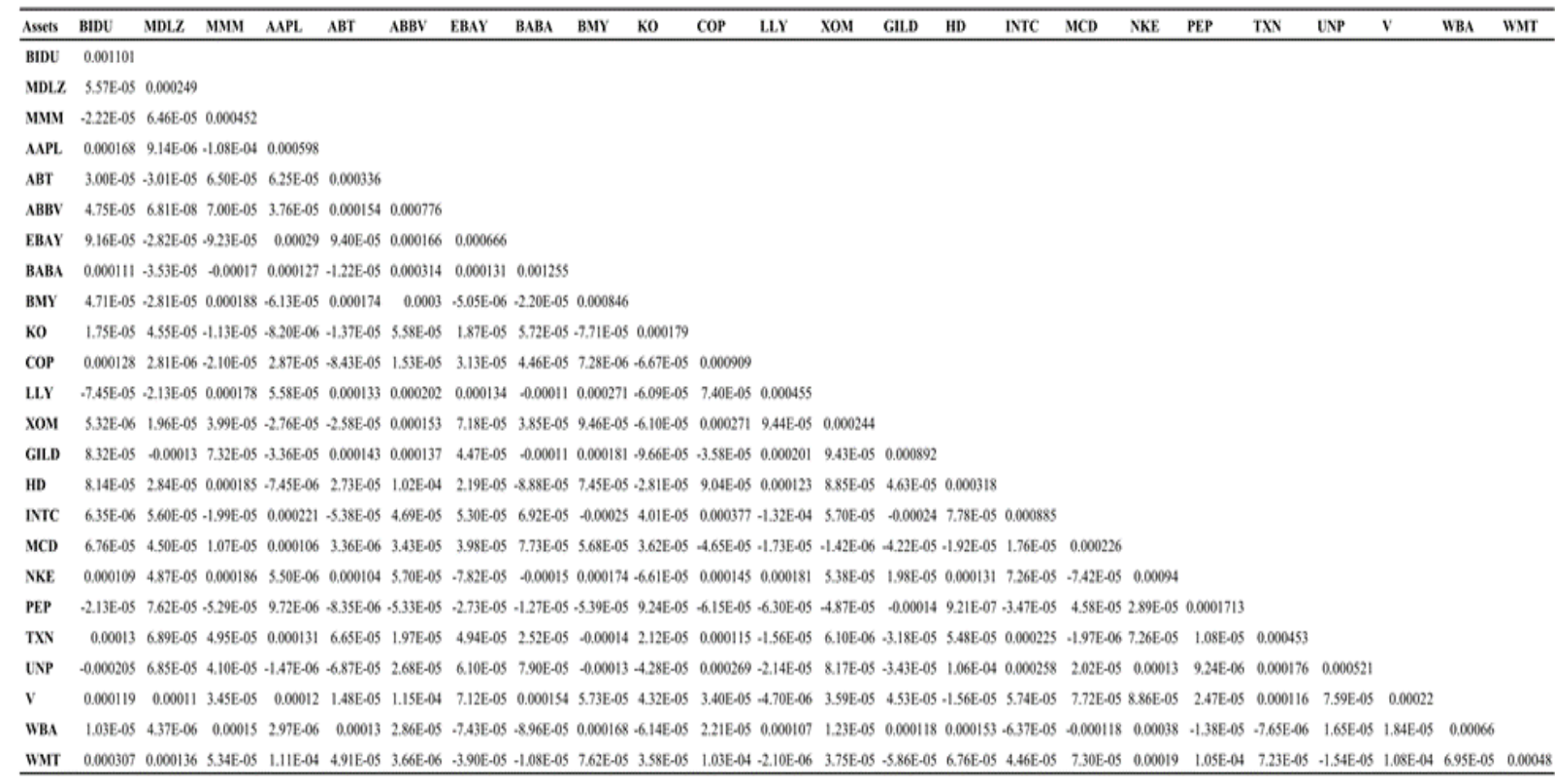

Table 3. Variance - Covariance matrix after adjustment. 


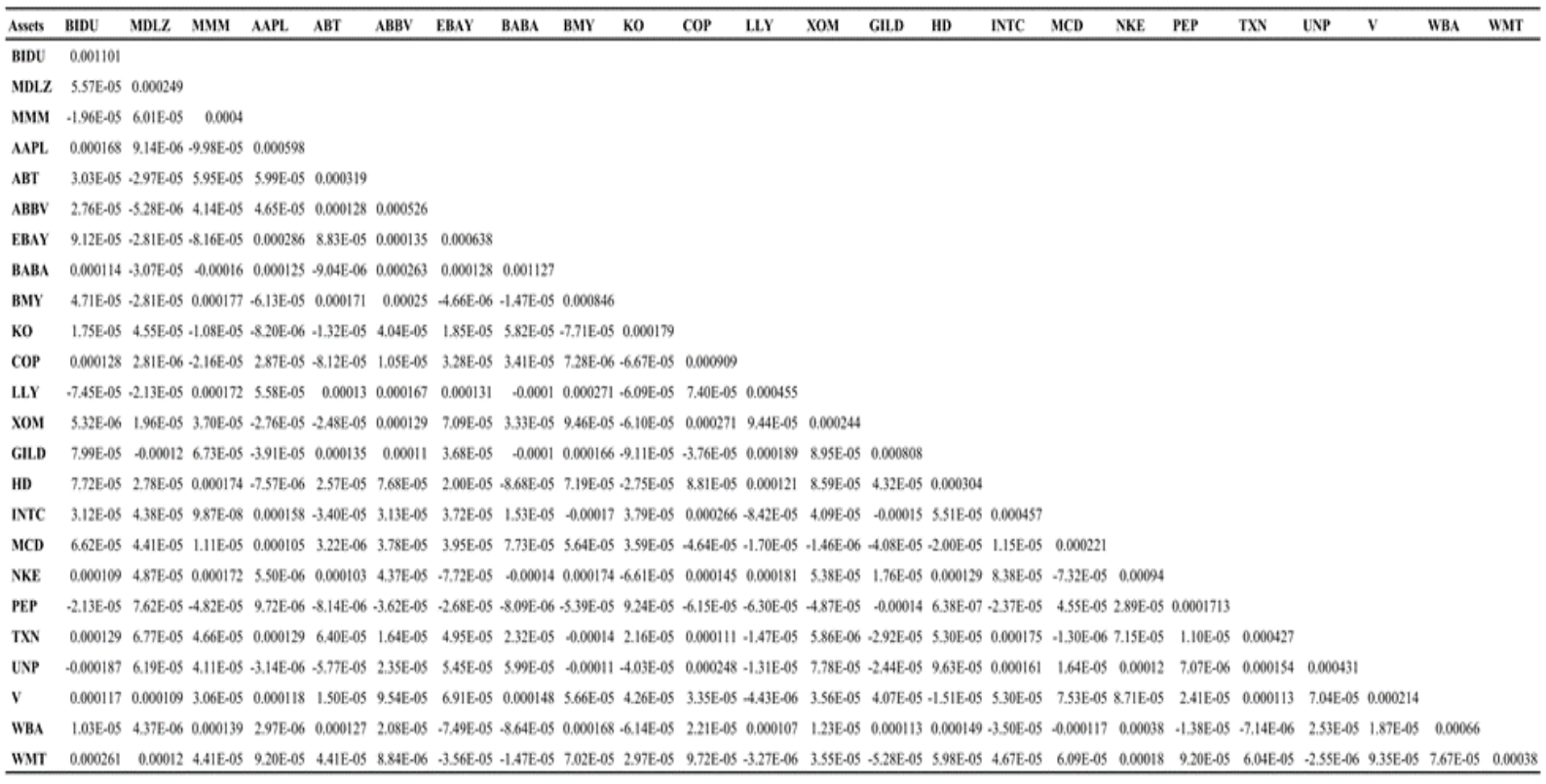

To prove this, we proceed to the simulation of both models using the MATLAB financial toolbox package. We obtained a 10-equidistance portfolio, which expresses the efficient frontier for both our portfolio's original and adjusted one.The results are given by both tables 4 and 5 .

Table 4. Optimal 10-equidistance portfolio using original variance-covariance matrix

\begin{tabular}{|c|c|c|c|c|c|c|c|c|c|c|c|}
\hline Assets & $\begin{array}{l}\text { port } \\
1\end{array}$ & $\begin{array}{l}\text { port } \\
2 \\
\end{array}$ & $\begin{array}{l}\text { port } \\
3 \\
\end{array}$ & $\begin{array}{l}\text { port } \\
4 \\
\end{array}$ & $\begin{array}{l}\text { port } \\
5 \\
\end{array}$ & $\begin{array}{l}\text { port } \\
6 \\
\end{array}$ & $\begin{array}{l}\text { port } \\
7 \\
\end{array}$ & $\begin{array}{l}\text { port } \\
8 \\
\end{array}$ & $\begin{array}{l}\text { port } \\
9 \\
\end{array}$ & $\begin{array}{l}\text { port } \\
10 \\
\end{array}$ & $\begin{array}{l}\text { Annualized } \\
\text { risk }\end{array}$ \\
\hline BIDU & $\begin{array}{l}0.022 \\
07\end{array}$ & $\begin{array}{l}0.021 \\
78\end{array}$ & $\begin{array}{l}0.005 \\
99\end{array}$ & 0 & 0 & 0 & 0 & 0 & 0 & 0 & 0.23928 \\
\hline $\begin{array}{l}\text { MDL } \\
\mathbf{Z}\end{array}$ & $\begin{array}{l}0.019 \\
41\end{array}$ & 0 & 0 & 0 & 0 & 0 & 0 & 0 & 0 & 0 & 0.11385 \\
\hline MMM & $\begin{array}{l}0.044 \\
64\end{array}$ & $\begin{array}{l}0.078 \\
10\end{array}$ & $\begin{array}{l}0.084 \\
86\end{array}$ & $\begin{array}{l}0.069 \\
09\end{array}$ & $\begin{array}{l}0.034 \\
68\end{array}$ & 0 & 0 & 0 & 0 & 0 & 0.15326 \\
\hline AAPL & $\begin{array}{l}0.025 \\
90\end{array}$ & $\begin{array}{l}0.032 \\
17\end{array}$ & $\begin{array}{l}0.033 \\
44\end{array}$ & $\begin{array}{l}0.024 \\
11\end{array}$ & $\begin{array}{l}0.005 \\
07\end{array}$ & 0 & 0 & 0 & 0 & 0 & 0.17630 \\
\hline ABT & $\begin{array}{l}0.057 \\
22\end{array}$ & $\begin{array}{l}0.095 \\
30\end{array}$ & $\begin{array}{l}0.122 \\
11\end{array}$ & $\begin{array}{l}0.141 \\
08\end{array}$ & $\begin{array}{l}0.161 \\
92\end{array}$ & $\begin{array}{l}0.117 \\
1\end{array}$ & $\begin{array}{l}0.061 \\
6\end{array}$ & 0 & 0 & 0 & 0.13222 \\
\hline ABBV & 0 & 0 & $\begin{array}{l}0.000 \\
7\end{array}$ & $\begin{array}{l}0.021 \\
6\end{array}$ & $\begin{array}{l}0.035 \\
8\end{array}$ & $\begin{array}{l}0.123 \\
4\end{array}$ & $\begin{array}{l}0.218 \\
2\end{array}$ & $\begin{array}{l}0.301 \\
7\end{array}$ & $\begin{array}{l}0.334 \\
0\end{array}$ & 0 & 0.20084 \\
\hline EBAY & 0 & 0 & $\begin{array}{l}0.002 \\
7\end{array}$ & 0 & 0 & 0 & 0 & 0 & 0 & 0 & 0.18614 \\
\hline BABA & $\begin{array}{l}0.020 \\
7\end{array}$ & $\begin{array}{l}0.046 \\
2\end{array}$ & $\begin{array}{l}0.072 \\
8\end{array}$ & 0.094 & 0.125 & 0.230 & 0.347 & 0.476 & 0.645 & 1 & 0.25548 \\
\hline BMY & $\begin{array}{l}0.009 \\
78\end{array}$ & 0 & 0 & 0 & 0 & 0 & 0 & 0 & 0 & 0 & 0.20975 \\
\hline KO & $\begin{array}{l}0.167 \\
48\end{array}$ & $\begin{array}{l}0.113 \\
62\end{array}$ & $\begin{array}{l}0.070 \\
25\end{array}$ & $\begin{array}{l}0.008 \\
13\end{array}$ & 0 & 0 & 0 & 0 & 0 & 0 & 0.09653 \\
\hline COP & 0 & $\begin{array}{l}0.004 \\
73\end{array}$ & $\begin{array}{l}0.030 \\
44\end{array}$ & $\begin{array}{l}0.021 \\
59\end{array}$ & 0 & 0 & 0 & 0 & 0 & 0 & 0.21746 \\
\hline LLY & $\begin{array}{l}0.034 \\
51\end{array}$ & $\begin{array}{l}0.021 \\
78\end{array}$ & 0 & 0 & 0 & 0 & 0 & 0 & 0 & 0 & 0.15387 \\
\hline XOM & $\begin{array}{l}0.144 \\
47\end{array}$ & $\begin{array}{l}0.102 \\
00\end{array}$ & $\begin{array}{l}0.023 \\
5\end{array}$ & 0 & 0 & 0 & 0 & 0 & 0 & 0 & 0.11257 \\
\hline GILD & $\begin{array}{l}0.061 \\
96\end{array}$ & $\begin{array}{l}0.053 \\
24\end{array}$ & $\begin{array}{l}0.048 \\
1\end{array}$ & $\begin{array}{l}0.019 \\
5\end{array}$ & 0 & 0 & 0 & 0 & 0 & 0 & 0.21536 \\
\hline HD & 0 & $\begin{array}{l}0.021 \\
54\end{array}$ & $\begin{array}{l}0.088 \\
56\end{array}$ & $\begin{array}{l}0.135 \\
44\end{array}$ & $\begin{array}{l}0.181 \\
29\end{array}$ & $\begin{array}{l}0.131 \\
07\end{array}$ & $\begin{array}{l}0.046 \\
55\end{array}$ & 0 & 0 & 0 & 0.12865 \\
\hline INTC & $\begin{array}{l}0.035 \\
92\end{array}$ & $\begin{array}{l}0.026 \\
89\end{array}$ & $\begin{array}{l}0.010 \\
30\end{array}$ & 0 & 0 & 0 & 0 & 0 & 0 & 0 & 0.21455 \\
\hline
\end{tabular}




\begin{tabular}{|c|c|c|c|c|c|c|c|c|c|c|c|}
\hline MCD & $\begin{array}{l}0.067 \\
7\end{array}$ & $\begin{array}{l}0.099 \\
3\end{array}$ & $\begin{array}{l}0.152 \\
8\end{array}$ & $\begin{array}{l}0.206 \\
6\end{array}$ & $\begin{array}{l}0.268 \\
2\end{array}$ & $\begin{array}{l}0.187 \\
6\end{array}$ & $\begin{array}{l}0.077 \\
8\end{array}$ & 0 & 0 & 0 & 0.10829 \\
\hline NKE & 0 & 0 & $\begin{array}{l}9 \mathrm{E}- \\
05\end{array}$ & 0 & 0 & 0 & 0 & 0 & 0 & 0 & 0.22095 \\
\hline PEP & $\begin{array}{l}0.204 \\
9\end{array}$ & $\begin{array}{l}0.212 \\
6\end{array}$ & $\begin{array}{l}2 \mathrm{E}- \\
01\end{array}$ & $\begin{array}{l}0.143 \\
5\end{array}$ & $\begin{array}{l}0.009 \\
1\end{array}$ & 0 & 0 & 0 & 0 & 0 & 0.09439 \\
\hline TXN & 0 & $\begin{array}{l}0.012 \\
78\end{array}$ & $\begin{array}{l}4 \mathrm{E}- \\
02\end{array}$ & $\begin{array}{l}0.066 \\
5\end{array}$ & $\begin{array}{l}0.097 \\
9\end{array}$ & $\begin{array}{l}0.105 \\
9\end{array}$ & $\begin{array}{l}0.102 \\
5\end{array}$ & $\begin{array}{l}0.068 \\
0\end{array}$ & 0 & 0 & 0.15351 \\
\hline UNP & $\begin{array}{l}0.041 \\
78\end{array}$ & $\begin{array}{l}0.044 \\
58\end{array}$ & $\begin{array}{l}3 \mathrm{E}- \\
02\end{array}$ & $\begin{array}{l}0.015 \\
9\end{array}$ & $\begin{array}{l}0.010 \\
3\end{array}$ & 0 & 0 & 0 & 0 & 0 & 0.16459 \\
\hline $\mathbf{V}$ & 0 & 0 & 0 & $\begin{array}{l}0.017 \\
4\end{array}$ & $\begin{array}{l}0.007 \\
2\end{array}$ & 0 & 0 & 0 & 0 & 0 & 0.10684 \\
\hline WBA & $\begin{array}{l}0.041 \\
53\end{array}$ & $\begin{array}{l}0.013 \\
46\end{array}$ & 0 & 0 & 0 & 0 & 0 & 0 & 0 & 0 & 0.18524 \\
\hline WMT & 0 & 0 & 0 & $\begin{array}{l}0.015 \\
2\end{array}$ & $\begin{array}{l}0.063 \\
6\end{array}$ & $\begin{array}{l}0.105 \\
0\end{array}$ & $\begin{array}{l}0.146 \\
7\end{array}$ & $\begin{array}{l}0.154 \\
6\end{array}$ & $\begin{array}{l}0.021 \\
1\end{array}$ & 0 & 0.15851 \\
\hline $\begin{array}{l}\text { Retur } \\
\text { n } \\
\text { Varia } \\
\text { nce }\end{array}$ & $\begin{array}{l}0.213 \\
07 \\
0.005 \\
64\end{array}$ & $\begin{array}{l}0.290 \\
98 \\
0.005 \\
91\end{array}$ & $\begin{array}{l}0.368 \\
89 \\
0.006 \\
64\end{array}$ & $\begin{array}{l}0.446 \\
80 \\
0.007 \\
75\end{array}$ & $\begin{array}{l}0.524 \\
72 \\
0.009 \\
28\end{array}$ & $\begin{array}{l}0.602 \\
63 \\
0.012 \\
10\end{array}$ & $\begin{array}{l}0.680 \\
54 \\
0.016 \\
45\end{array}$ & $\begin{array}{l}0.758 \\
45 \\
0.021 \\
48\end{array}$ & $\begin{array}{l}0.836 \\
36 \\
0.027 \\
28\end{array}$ & $\begin{array}{l}0.914 \\
27 \\
0.035 \\
43\end{array}$ & \\
\hline
\end{tabular}

The table 4 shows the top 10-equidistance optimal portfolio consists of 24 assets.

Table 5. Optimal 10-equidistance portfolio using adjusted variance-covariance matrix

\begin{tabular}{|c|c|c|c|c|c|c|c|c|c|c|c|}
\hline Assets & $\begin{array}{l}\text { port } \\
1\end{array}$ & $\begin{array}{l}\text { port } \\
2\end{array}$ & $\begin{array}{l}\text { port } \\
\mathbf{3} \\
\end{array}$ & $\begin{array}{l}\text { port } \\
4 \\
\end{array}$ & $\begin{array}{l}\text { port } \\
5 \\
\end{array}$ & $\begin{array}{l}\text { port } \\
6 \\
\end{array}$ & $\begin{array}{l}\text { port } \\
7 \\
\end{array}$ & $\begin{array}{l}\text { port } \\
8 \\
\end{array}$ & $\begin{array}{l}\text { port } \\
9 \\
\end{array}$ & $\begin{array}{l}\text { port } \\
10\end{array}$ & $\begin{array}{l}\text { Annualized } \\
\text { risk }\end{array}$ \\
\hline BIDU & $\begin{array}{l}0.018 \\
83\end{array}$ & $\begin{array}{l}0.021 \\
57\end{array}$ & $\begin{array}{l}0.005 \\
68\end{array}$ & 0 & 0 & 0 & 0 & 0 & 0 & 0 & 0.23928 \\
\hline $\begin{array}{l}\text { MDL } \\
\mathbf{Z}\end{array}$ & $\begin{array}{l}0.017 \\
91\end{array}$ & 0 & 0 & 0 & 0 & 0 & 0 & 0 & 0 & 0 & 0.11385 \\
\hline $\begin{array}{l}\text { MM } \\
\mathbf{M}\end{array}$ & $\begin{array}{l}0.050 \\
46\end{array}$ & $\begin{array}{l}0.084 \\
56\end{array}$ & $\begin{array}{l}0.097 \\
30\end{array}$ & $\begin{array}{l}0.077 \\
63\end{array}$ & $\begin{array}{l}0.044 \\
88\end{array}$ & 0 & 0 & 0 & 0 & 0 & 0.14431 \\
\hline AAPL & $\begin{array}{l}0.018 \\
50\end{array}$ & $\begin{array}{l}0.025 \\
32\end{array}$ & $\begin{array}{l}0.019 \\
20\end{array}$ & $\begin{array}{l}0.016 \\
21\end{array}$ & $\begin{array}{l}0.003 \\
51\end{array}$ & 0 & 0 & 0 & 0 & 0 & 0.17630 \\
\hline ABT & $\begin{array}{l}0.054 \\
28\end{array}$ & $\begin{array}{l}0.096 \\
91\end{array}$ & $\begin{array}{l}0.108 \\
95\end{array}$ & $\begin{array}{l}0.126 \\
38\end{array}$ & $\begin{array}{l}0.142 \\
40\end{array}$ & $\begin{array}{l}0.091 \\
44\end{array}$ & $\begin{array}{l}0.025 \\
70\end{array}$ & 0 & 0 & 0 & 0.12879 \\
\hline $\begin{array}{l}\mathbf{A B B} \\
\mathbf{V}\end{array}$ & 0 & 0 & $\begin{array}{l}0.021 \\
4\end{array}$ & $\begin{array}{l}0.049 \\
5\end{array}$ & $\begin{array}{l}0.073 \\
9\end{array}$ & $\begin{array}{l}0.180 \\
8\end{array}$ & $\begin{array}{l}0.304 \\
2\end{array}$ & $\begin{array}{l}0.393 \\
6\end{array}$ & $\begin{array}{l}0.372 \\
7\end{array}$ & 0 & 0.16532 \\
\hline $\begin{array}{l}\text { EBA } \\
\mathbf{Y}\end{array}$ & $\begin{array}{l}0.004 \\
45\end{array}$ & 0 & $\begin{array}{l}0.010 \\
7\end{array}$ & 0 & 0 & 0 & 0 & 0 & 0 & 0 & 0.18215 \\
\hline $\begin{array}{l}\mathbf{B A B} \\
\mathbf{A}\end{array}$ & $\begin{array}{l}0.025 \\
55\end{array}$ & $\begin{array}{l}0.052 \\
56\end{array}$ & $\begin{array}{l}0.074 \\
70\end{array}$ & $\begin{array}{l}0.094 \\
65\end{array}$ & $\begin{array}{l}0.119 \\
02\end{array}$ & $\begin{array}{l}0.204 \\
05\end{array}$ & $\begin{array}{l}0.303 \\
87\end{array}$ & $\begin{array}{l}0.432 \\
25\end{array}$ & $\begin{array}{l}0.627 \\
26\end{array}$ & 1 & 0.24205 \\
\hline BMY & $\begin{array}{l}0.009 \\
9\end{array}$ & 0 & 0 & 0 & 0 & 0 & 0 & 0 & 0 & 0 & 0.20975 \\
\hline KO & $\begin{array}{l}0.142 \\
5\end{array}$ & $\begin{array}{l}0.089 \\
92\end{array}$ & $\begin{array}{l}0.033 \\
52\end{array}$ & 0 & 0 & 0 & 0 & 0 & 0 & 0 & 0.09653 \\
\hline COP & 0 & 0 & $\begin{array}{l}0.026 \\
38\end{array}$ & $\begin{array}{l}0.010 \\
16\end{array}$ & 0 & 0 & 0 & 0 & 0 & 0 & 0.21746 \\
\hline LLY & $\begin{array}{l}0.033 \\
09\end{array}$ & $\begin{array}{l}0.023 \\
21\end{array}$ & 0 & 0 & 0 & 0 & 0 & 0 & 0 & 0 & 0.15387 \\
\hline XOM & $\begin{array}{l}0.130 \\
25\end{array}$ & $\begin{array}{l}0.091 \\
44\end{array}$ & $\begin{array}{l}0.006 \\
30\end{array}$ & 0 & 0 & 0 & 0 & 0 & 0 & 0 & 0.11257 \\
\hline GILD & $\begin{array}{l}0.068 \\
48\end{array}$ & $\begin{array}{l}0.058 \\
34\end{array}$ & $\begin{array}{l}0.057 \\
81\end{array}$ & $\begin{array}{l}0.026 \\
87\end{array}$ & 0 & 0 & 0 & 0 & 0 & 0 & 0.20494 \\
\hline HD & 0 & $\begin{array}{l}0.020 \\
28\end{array}$ & $\begin{array}{l}0.073 \\
22\end{array}$ & $\begin{array}{l}0.111 \\
73\end{array}$ & $\begin{array}{l}0.154 \\
02\end{array}$ & $\begin{array}{l}0.120 \\
95\end{array}$ & $\begin{array}{l}0.036 \\
94\end{array}$ & 0 & 0 & 0 & 0.12578 \\
\hline INTC & $\begin{array}{l}0.067 \\
06\end{array}$ & $\begin{array}{l}0.061 \\
94\end{array}$ & $\begin{array}{l}0.049 \\
93\end{array}$ & $\begin{array}{l}0.028 \\
04\end{array}$ & 0 & 0 & 0 & 0 & 0 & 0 & 0.15413 \\
\hline MCD & $\begin{array}{l}0.067 \\
97\end{array}$ & $\begin{array}{l}0.093 \\
54\end{array}$ & $\begin{array}{l}0.140 \\
71\end{array}$ & $\begin{array}{l}0.185 \\
23\end{array}$ & $\begin{array}{l}0.235 \\
91\end{array}$ & $\begin{array}{l}0.163 \\
53\end{array}$ & $\begin{array}{l}0.051 \\
78\end{array}$ & 0 & 0 & 0 & 0.10726 \\
\hline
\end{tabular}




\begin{tabular}{|l|llllllllll|l|} 
PEP & 0.213 & 0.219 & 0.214 & 0.142 & 0.015 & 0 & 0 & 0 & 0 & 0 & 0.09439 \\
& 32 & 07 & 69 & 35 & 12 & 0.027 & & & \\
TXN & 0 & 0.003 & 0.027 & 0.058 & 0.091 & 0.103 & 0.099 & 0.032 & & & \\
& 41 & 99 & 35 & 25 & 4 & 7 & 3 & 0 & 0 & 0.14894 \\
UNP & 0.038 & 0.048 & 0.024 & 0.026 & 0.023 & 0 & 0 & 0 & 0 & 0 & 0.14967 \\
& 91 & 86 & 51 & 54 & 85 & & & & & & \\
WBA & 0.038 & 0.009 & 0 & 0 & 0 & 0 & 0 & 0 & 0 & 0 & 0.18524 \\
& 50 & 07 & 0.006 & 0.046 & 0.096 & 0.135 & 0.177 & 0.141 & & & \\
WMT & 0 & 0 & 94 & 37 & 13 & 89 & 77 & 83 & 0 & 0 & 0.13982 \\
\hline retur & 0.220 & 0.297 & 0.374 & 0.451 & 0.528 & 0.605 & 0.682 & 0.759 & 0.837 & 0.914 & \\
n & 01 & 15 & 29 & 43 & 57 & 71 & 85 & 99 & 13 & 27 & \\
varia & 0.005 & 0.005 & 0.006 & 0.007 & 0.008 & 0.011 & 0.015 & 0.019 & 0.025 & 0.033 & \\
nce & 53 & 80 & 50 & 54 & 93 & 38 & 19 & 75 & 28 & 57 &
\end{tabular}

Table 5 gives us the optimal composition of the 10-equidistance portfolio obtained by the simulation of the adjusted variance-covariance matrix. We notice thatthe optimization leads to a portfolio consisting of 22 securities. The assets 'NKE' and 'V'did not take part in this portfolio.

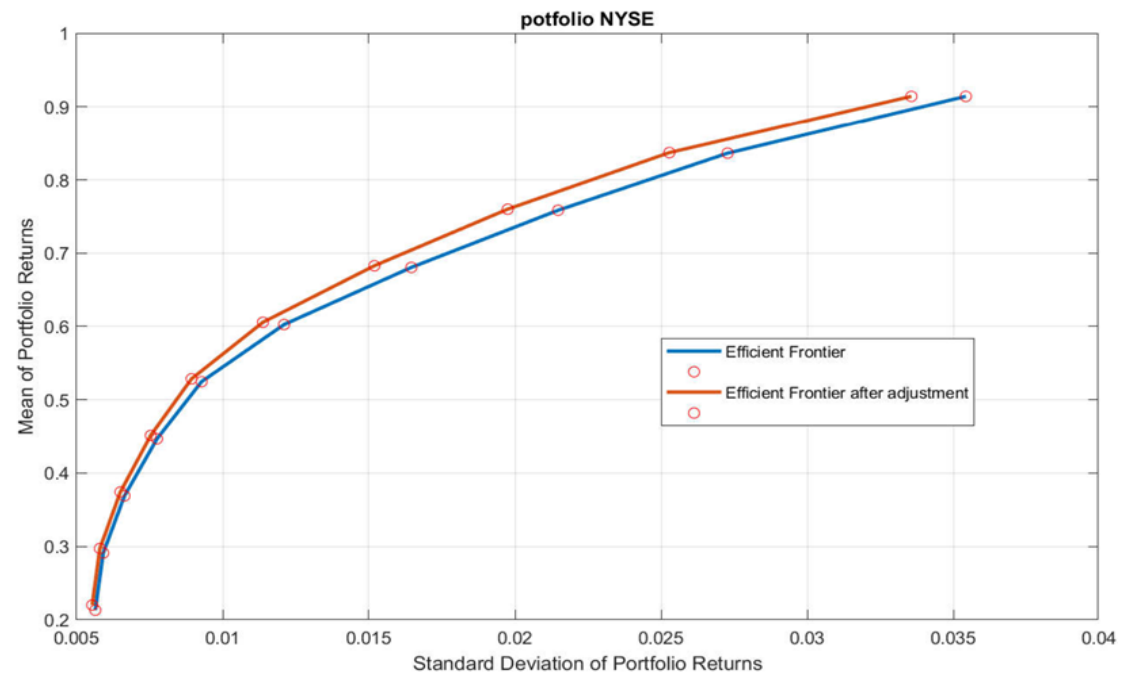

Figure 2. Efficiency frontier before and after adjustment of variance- covariance matrix.

After plotting the efficient frontier for both portfolios, we can observe that the adjusted efficient frontier has less risky and higher returns. This proves that the adjustment that we applied has changed the composition of our portfolio, whereas our adjustment only changed the positive semi-variance. In our case, the positive semi-variance does not represent a risk (no short selling allowed).

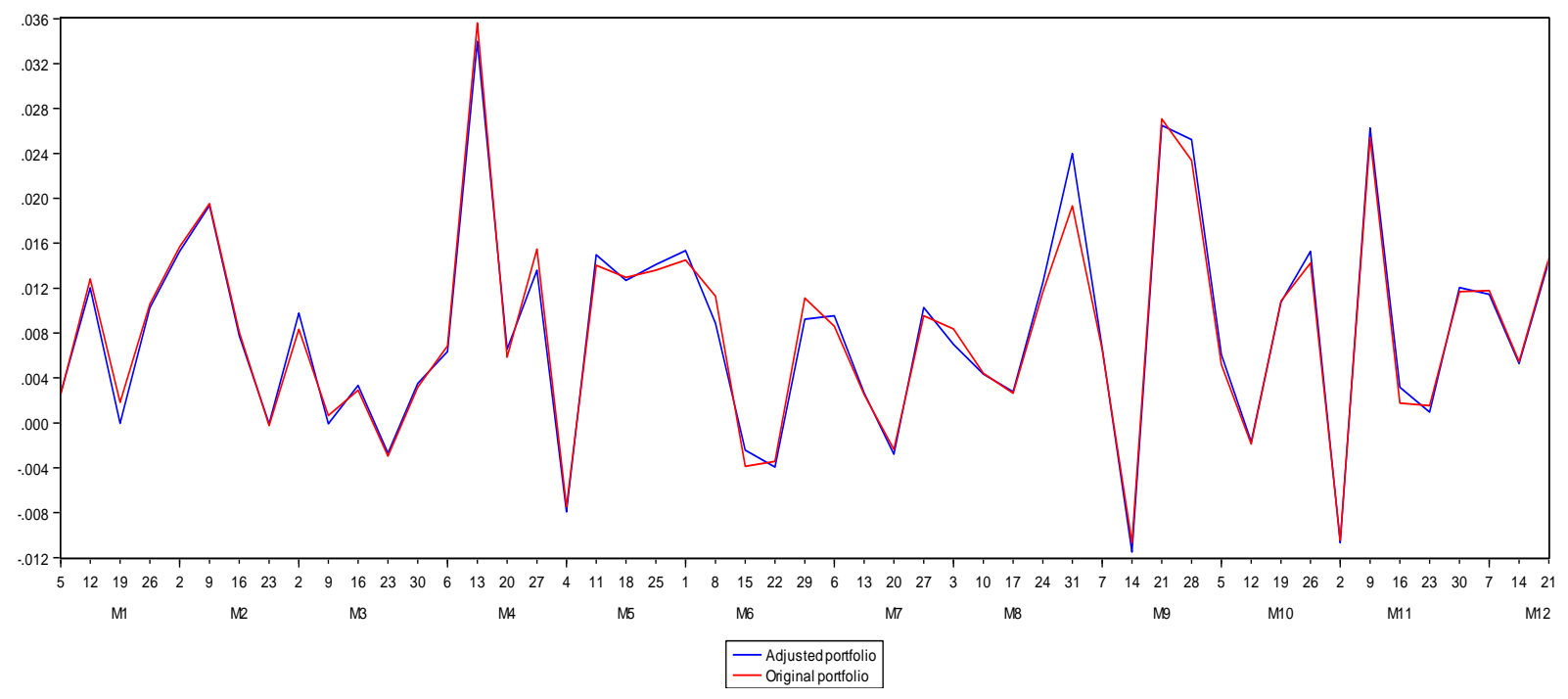


Figure 3. Evolotion of portfolio $\mathrm{N}^{\circ} 5$ return befor and after adjustment

Figure 3 shows that the adjusted portfolio tends to have more positive returns than the original one. Also, table 6 confirms our result, the return and risk of the fifth portfolio show much difference between the original and adjusted portfolio.

Table 6. Risk and return of the fifth portfolio before and after adjustment

\begin{tabular}{lll}
\hline \multirow{2}{*}{ adjusted portfolio } & return & 0.52857 \\
& variance & 0.00893 \\
original portfolio & return & 0.52472 \\
& variance & 0.00928 \\
\hline
\end{tabular}

\section{Conclusion}

Since the security market is intricate, some assets hide their true risk. Thereby, in this paper, we try to examine the symmetryof risk, sincetaking the same risk for both upward and downward shocks is rarely observed in the market. Accordingly, we adjust the variance-covariance matrix by equalizing the two (up and down) semi variances. This procedure removes a part of risk which is unnecessary and only disturbs our optimization.

After the numerical computationof our model using both mean-variance models and mean adjusted variance models, the obtained result shows that the adjusted model has more return and less risk than the classical meanvariance model, this portfolio will reflect the true value of risk to investors. In our future research,we will be adding the transaction coast, as well assome investment restrictions trying to test the flexibility and usability of this model.

\section{References}

1. Alexander, G.J., \& Baptista, A.M. (2004). A comparison of VaR and CVaR constraints on portfolio selection with the mean-variance model. Management science, 50(9), 1261-1273.

2. Arditti, F.D. (1967). Risk and the required return on equity. The Journal of Finance, 22(1), 19-36.

3. Baker, H.K., \& Filbeck, G. (Eds.). (2013). Portfolio theory and management. Oxford University Press.

4. Bawa, V.S., \& Lindenberg, E.B. (1977). Capital market equilibrium in a mean-lower partial moment framework. Journal of financial economics, 5(2), 189-200.

5. Benati, S., \& Rizzi, R. (2007). A mixed integer linear programming formulation of the optimal mean/value-at-risk portfolio problem. European Journal of Operational Research, 176(1), 423-434.

6. Briec, W., Kerstens, K., \& Jokung, O. (2007). Mean-variance-skewness portfolio performance gauging: a general shortage function and dual approach. Management science, 53(1), 135-149.

7. Clash, J.M. (1999). Focus on the downside. Forbes, 163(4), 162-163.

8. Deng, X., Li, Z., \& Wang, S. (2005). Aminimax portfolio selection strategy with equilibrium. European Journal of Operational Research, 166(1), 278-292.

9. Estrada, J. (2000). The cost of equity in emerging markets: a downside risk approach.

10. Estrada, J. (2001). The cost of equity in emerging markets: A downside risk approach (II). Emerging Markets Quarterly, 63-72.

11. Estrada, J. (2004). The cost of equity of internet stocks: A downside risk approach. European Journal of Finance, 10, 239-254.

12. Arditti, F.D. (1971). Another look at mutual fund performance. Journal of Financial and Quantitative Analysis, 6(3), 909-912.

13. Fang, H., \& Lai, T.Y. (1997). Co-kurtosis and capital asset pricing. Financial Review, 32(2), 293-307.

14. Feldstein, M. S. (1969). Mean-variance analysis in the theory of liquidity preference and portfolio selection. The Review of Economic Studies, 36(1), 5-12.

15. Grama, Y., \& Schyns,M. (2003). Simulated annealing for complex portfolio selection problems. European Journal of Operational Research, 150(3), 546-571.

16. Guo, Q., Li, J., Zou, C., Guo, Y., \& Yan, W. (2012). A class of multi- period semi-variance portfolio for petroleum exploration and development. International Journal of Systems Science, 43(10), 1883- 1890.

17. Konno, H., \& Suzuki, K.I. (1995). A mean-variance-skewness portfolio optimization model. Journal of the Operations Research Society of Japan, 38(2), 173-187.

18. Hamza, F., \& Janssen, J. (1998). The mean-semi variances approach to realistic portfolio optimization subject to transaction costs. Applied stochastic models and data analysis, 14(4), 275-283.

19. Hamza, F., \& Janssen, J. (2009). Optimal choice of financial assets and portfolio management . Hermès Science. 
20. Harlow, V., \& Rao, R. (1989). Asset pricing in a generalized mean-lower partial moment framework: Theory and evidence. Journal of Financial and Quantitative Analysis, 24, 285-311.

21. Harlow, W.V. (1991). Asset allocation in a downside-risk framework. Financial analysts journal, 47(5), 28-40.

22. Harvey, C.R. (2000). The drivers of expected returns in international markets. Available at SSRN 795385.

23. Hwang, S., \& Pedersen, C.S. (2002). Best practice risk measurement in emerging markets: empirical test of asymmetric alternatives to CAPM. In Working Paper, Cass Business School, UK.

24. Iancu, D.A., \& Trichakis, N. (2014). Fairness and efficiency in multiportfolio optimization. Operations Research, 62(6), 1285-1301.

25. Jeffrey, R.H. (1984). The folly of stock-market timing. Harvard Business Review, 62(4), 102-110.

26. Jondeau, E., \& Rockinger, M. (2002). Asset Allocation in Transition Economies.

27. Konno, H., Shirakawa, H., \& Yamazaki, H. (1993). A mean-absolute deviation-skewness portfolio optimization model. Annals of Operations Research, 45(1), 205-220.

28. Lai, K.K., Yu, L., Wang, S., \& Zhou, C. (2006). A double-stage genetic optimization algorithm for portfolio selection. In International Conference on Neural Information Processing, Springer, Berlin, Heidelberg, 928-937.

29. Mansini, R., Ogryczak, W., \& Speranza, M.G. (2007). Conditional value at risk and related linear programming models for portfolio optimization. Annals of operations research, 152(1), 227-256.

30. Mansinia, R., Ogryczakb, W., \& Speranzac, M. (2014).Twenty years of linear programming based portfolio optimization. European Journal of Operational Research, 234(2), 518-535.

31. Mao, J.C. (1970). Models of capital budgeting, EV vs ES. Journal of financial and quantitative analysis, 4(5), 657-675.

32. Markowitz H.M. (1952). Portfolio selection. Journal of Finance, 7(1), 77-91.

33. Markowitz, H. (1959). Portfolio selection, efficent diversification of investments. J. Wiley.

34. Ogryczak, W. (2000). Multiple criteria linear programming model for portfolio selection. Annals of Operations Research, 97(1), 143-162.

35. Chunhachinda, P., Dandapani, K., Hamid, S., \& Prakash, A.J. (1997). Portfolio selection and skewness: Evidence from international stock markets. Journal of Banking \& Finance, 21(2), 143-167.

36. Prakash, A.J., Chang, C.H., \& Pactwa, T.E. (2003). Selecting a portfolio with skewness: Recent evidence from US, European, and Latin American equity markets. Journal of Banking \& Finance, 27(7), 13751390.

37. Reilly, F.K. (1985). Investment analysis and portfolio management, 2nd ed., Dryden Press, Hinsdale.

38. Roy, A.D. (1952). Safety first and the holding of assets. Econometrica: Journal of the econometric society, 431-449.

39. Rubinstein, M.E. (1973). The fundamental theorem of parameter-preference security valuation. Journal of Financial and Quantitative Analysis, 61-69.

40. Liu, S.Y.W.S., Wang, S.Y., \& Qiu, W. (2003). Mean-variance-skewness model for portfolio selection with transaction costs. International Journal of Systems Science, 34(4), 255-262.

41. Samuelson, P.A. (1975). The fundamental approximation theorem of portfolio analysis in terms of means, variances and higher moments. In Stochastic Optimization Models in Finance, Academic Press, 215-220.

42. Sawik, B. (2010). A bi-objective portfolio optimization with conditional value-at-risk. Decision Making in Manufacturing and Services, 4(2), 47-69.

43. Sawik, B. (2009). A reference point approach to bi-objective dynamic portfolio optimization. Decision Making in Manufacturing and Services, 3(2), 73-85.

44. Sawik, B. (2008). A three stage lexicographic approach for multi-criteria portfolio optimization by mixed integer programming. Przeglad Elektrotechniczny, 84(9), 108-112.

45. Sawik, B. (2009). A weighted-sum mixed integer program for bi--objective dynamic portfolio optimization. Automatyka/Akademia Górniczo-Hutnicza im. Stanisława Staszica w Krakowie, 13(2), 563571.

46. Sawik, B. (2009). Lexicographic and weighting approach to multi-criteria portfolio optimization by mixed integer programming. Financial Modeling Applications and Data Envelopment Applications, 318 .

47. Sawik, B. (2010). Selected multi objective methods for multiperiod portfolio optimization by mixed integer programming. Applications of Management Science, 3-34.

48. Sawik, B. (2011). Conditional value-at-risk and value-at-risk for portfolio optimization model with weighting approach. Automatyka/Akademia Górniczo-Hutnicza im. Stanisława Staszica w Krakowie, 15, 429-434.

49. Sawik, B. (2012). Bi-criteria portfolio optimization models with percentile and symmetric risk measures by mathematical programming. Przeglad Elektrotechniczny, 88(10B), 176-180. 
50. Sawik, B. (2012). Downside risk approach for multi-objective portfolio optimization. In Operations Research Proceedings 2011, Springer, Berlin, Heidelberg, 191-196.

51. Sawik, B.T. (2012). Conditional value-at-risk vs. value-at-risk to multi-objective portfolio optimization. In Applications of management science, Emerald Group Publishing Limited, 277-305.

52. Sawik, T. (2013). Integrated selection of suppliers and scheduling of customer orders in the presence of supply chain disruption risks. International Journal of Production Research, 51(23-24), 7006-7022.

53. Sawik, T. (2013). Selection of resilient supply portfolio under disruption risks. Omega, 41(2), 259-269.

54. Scott, R.C., \& Horvath, P.A. (1980). On the direction of preference for moments of higher order than the variance. The Journal of Finance, 35(4), 915-919.

55. Sortino, F.A. (2009). The Sortino Framework for Constructing Portfolios: Focusing on Desired Target ReturnTM to Optimize Upside Potential Relative to Downside Risk. Elsevier.

56. Sortino, F.A., \& Satchell, S. (Eds.). (2001). Managing downside risk in financial markets. Elsevier.

57. Sortino, F.A., \& Van Der Meer, R. (1991). Downside risk. Journal of portfolio Management, 17(4), 27.

58. Sortino, F.A., Van Der Meer, R., \& Plantinga, A. (1999). The dutch triangle. The Journal of Portfolio Management, 26(1), 50-57.

59. Speranza, M.G. (1993). Linear programming models for portfolio optimization. Finance, 14, 107-123.

60. Lai, T.Y. (1991). Portfolio selection with skewness: a multiple-objective approach. Review of Quantitative Finance and Accounting, 1(3), 293-305.

61. Terradez, M., Kizys, R., Juan, A.A., Debon, A.M., \& Sawik, B. (2015). Risk scoring models for trade credit in small and medium enterprises. In Theory and Practice of Risk Assessment, Springer, Cham, 349360.

62. Tobin, J. (1958). Liquidity preference as behavior towards risk. The review of economic studies, 25(2), 65-86.

63. Yan, W., \& Li, S. (2009). Futures price modeling under exchange rate volatility and its multi-period semi-variance portfolio selection. International Journal of Systems Science, 40(11), 1139-1148. 